\title{
Positional verbs: derivation, semantics and functioning
}

\author{
INNA STUPAK \\ South Ukrainian National Pedagogical University named after K.D. Ushynsky \\ Faculty of Foreign Languages \\ 65000 Odessa (Ukraine) \\ E-mail: stupakinna@pdpu.edu.ua
}

POSITIONAL VERBS: DERIVATION, SEMANTICS AND FUNCTIONING

\section{VERBOS POSICIONALES: DERI- VACIÓN, SEMÁNTICA Y FUNCIO- NAMIENTO}

\begin{abstract}
This research is based on the universal theory of the lexical-semantic category of causation. Taking into account the absence of the grammatical category of causation in German and Ukrainian, I consider the possibility that it is compensated by the corresponding word-formation category comprised positional derived causative verbs. They semantically encode the change of the body position of animate beings as well as the location of inanimate objects in space. Although the positional verbs have been described in many languages, the semantic features of positional causative verbs have never been previously investigated in German and Ukrainian, which accounts for the novelty of the research. The derivation and semantics of positional derived causative verbs are analyzed to show how typologically different languages, on the one hand, have similarity in expressing the basic concepts of positional causative situation. But on the other hand, they differ in the spatial representation.
\end{abstract}

KEY WORDS: derived causative verb; positional verb; motivation stem; semantic role; semantic models.

SUMMARY: 1. Introduction. 2. Corpus and methodology: the problems outlined. 3. General characteristics of positional derived causative verbs in the German and Ukrainian languages. 3.1. The positional derived causative verbs with the meaning 'to cause to put into a body position or positional'. 3.2. The positional derived causative verbs with the meaning 'to cause to get into the spatial position up/down'. 3.3. The positional derived causative verbs with the meaning 'to cause to put into a spatial position as for a point'. 3.4. The positional derived causative verbs with the meaning 'to cause to be in a distance from the point'. 4 . Conclusions
RESUMEN: Este articulo se basa en la teoría universal de la categoría de causalidad léxico-semántica y su carácter especifico. Teniendo en cuenta la ausencia de la categoría gramatical de la causación en ambos idiomas, considero la posibilidad de que se compense con la categoría de formación de palabras correspondiente comprendida por los verbos causativos derivados de la posición. Los verbos causales posicionales se utilizan en este estudio como un término general que se refiere a una clase de verbos causales que codifican semánticamente la postura corporal estática o la posición de los seres animados o la ubicación estática de los objetos inanimados en el espacio. Aunque los verbos de posición se han descrito en muchos idiomas, sus características semánticas nunca se han explorado en alemán y ucraniano. La derivación y la semántica de los verbos causativos derivados de la posición se analizan para mostrar cómo lenguajes tipológicamente diferentes, por un lado, tienen similitud en la expresión de los conceptos básicos de la situación causal posicional. Pero, por otro lado, difieren en la representación espacial.

PALABRAS CLAVE: verbo causativo derivado; verbo posicional; raiz de motivación; rol semántico; modelos semánticos.

SUMARIO: 1. Introducción. 2. Metodologia. 3. Resultados. 3.1. Los verbos causativos derivados de la posición con el significado de "hacer que se ponga en una posición corporal o posicional". 3.2 Los verbos causativos derivados de la posición con el significado de "hacer que se coloque en la posición espacia vos derivados de la posición con el significado de "hacer que se coloque en una posición espacial como para un punto". 3.4. Los verbos causativos derivados de la posición con el significado de "hacer que esté a distancia del punto". 4. Conclusiones y discusión arriba/abajo". 3.3. Los verbos causati-
VERBES POSITIONNELS : DÉRIVA TION, SÉMANTIQUE ET FONCTIONNEMENT

RÉSUMÉ : Cet article est basé sur la théorie du caractère universel de la catégorie de causalité lexico-sémantique et de son caractère spécifique. Compte tenu de l'absence de la catégorie grammaticale de causalité dans les deux langues, j'envisage la possibilité qu'elle soit compensée par la catégorie de formation de mots correspondante, constituée par les verbes causatifs dérivés positionnels. Les verbes causatifs de position sont utilisés dans cette étude comme un terme générique qui désigne une classe de verbes causatifs qui encodent sémantiquement la positional corporelle statique ou la position des êtres animés ou la position statique des objets inanimés dans l'espace. Bien que les verbes de position aient été décrits dans de nombreuses langues, leurs caractéristiques sémantiques n'ont jamais été explorées auparavant en allemand et en ukrainien. La dérivation et la sémantique des verbes causatifs dérivés positionnels sont analysées pour montrer comment des langues typologiquement différentes, d'une part, ont une similitude dans l'expression des concepts de base de situation causative positionnelle. Mais d'un autre côté, ils diffèrent dans la représentation spatiale.

MOTS CLÉS : verbe causatif dérivé ; verbe de position ; racine de motivation ; rôle sémantique ; modèles sémantiques.

SOMMAIRE : 1 . Introduction. 2. Méthodologie. 3. Résultats. 3.1. Les verbes causatifs dérivés positionnels avec le sens " provoquer la mise en position corporelle ou positionnelle ". 3.2. Les verbes causatifs dérivés de la position avec le sens " faire entrer dans la position spatiale haut/bas ". 3.3. Les verbes causatifs dérivés positionnels avec le sens "faire mettre dans une position spatiale comme pour un point ". 3.4. Les verbes causatifs dérivés positionnels avec le sens " faire se trouver à une distance du point ". 4. Conclusions et discussion. 


\section{Positional verbs: derivation, semantics and functioning}

INNA STUPAK

\section{INTRODUCCIÓN}

Causal relations, as one of the main forms of interconnection of processes and phenomena of objective reality, are known to be the most important relations reflected in language. Increased interest in the study of means of expression of causality is due to the fact that they are a large and communicatively important group. A significant number of works is devoted to the study of causal relationships (Abusch, 1986; Nedyalkov, 1971; Persson, 1975; Silnitsky, 1969; Wunderlich, 1997).

Despite the large number of studies, the concept of "causality" remains controversial because it reflects the proximity of causative, causal, target and resulting values. In general, the semantics of causality can be considered from two points of view: ontological $\rightarrow$ through the concept of "causality"/"causation" (Nedyalkov, 1971; Nedyalkov and Silnitsky, 1969), and pragmatic $\rightarrow$ "motivation" (Comrie, 1976; Shibatani, 1964). In the latter case, causative means construction where the person acts as an agent.

In the study, causality is considered from the standpoint of the ontological approach. Thus, the concept of causality is associated with the expression of causal relations in language, when one action causes another action or state (Comrie and Polinsky, 1993; Heringer, 1984: 89; Nedyalkov, 1971: 166; Persson, 1979: 32).

The reviewed literature specifies the main contribution of Nedyalkov and Silnitsky to the development of the theory of causative (Nedyalkov \& Silnitsky, 1969), the study of analytical causative in German (Nedyalkov, 1971 and 1988) and morphological causative in English (Silnitsky, 1974). Thus, the universal typological category of causality can be expressed on the different levels (lexical, morphological, syntactic). On the morphological level the causality includes the following means of expression:

a) special affixes to form morphological causatives. Such languages as Turkic, Iranian, Finno-Ugric, Chinese, Japanese are characterized by morphological causative.

b) suppletive means by contrasting of a non-causative/causative opposition, which is expressed by the opposition of multi-rooted morphemes, for example: sterben 'to die' - töten 'to kill'.

c) word-formation means to build so called lexical causatives, for example: der Gips' plaster' $\rightarrow$ ausgipsen' mit Gips ausfüllen“ 'to fill with plaster'.

Nedyalkov (Nedyalkov, 1969: 303) drew attention to the fact that among all types of causative relations: connective, preposition, noun, verb; the latter is of particular interest as the verb is not only semantic, but also the grammatical core of the causative construction. In this regard, the causative constructions attracted the attention lots of linguists and their research took 
place in different directions: historical, comparative and typological, lexicalsemantic (Lakoff, 1968; Comrie, 1985; Persson, 1992; Talmy, 1976).

Along with the study of causative constructions, the lexical and grammatical properties of causative verbs, the nature of syntactic connections between the components of causative constructions were also studied (Comrie and Polinsky, 1993; Kaliuščenko, 1988; Kutscher, 2009; Stupak, 2010).

Of particular relevance is the issue that requires a comparative study of derived causative verbs based on the languages of different typological groups (German and Ukrainian). For German and Ukrainian the morphological causative is unproductive way to express causality. Both languages use a free form, and the causality is conveyed by lexical, analytic or syntactic ways. Despite the absence of special grammatical causative morphemes, which can form causative verb from any transitive or intransitive verb, German and Ukrainian have ways to express causality but differ in the means.

The causative meaning is conveyed by lexical means, in particular, by causative verbs. The present study is based on the lexical causatives, namely derived causative verbs. The specificity of derived verbs is: a) the number of semantic groups that are formed by word-forming affixes; b) additional features that are transmitted by word-formation means (mainly prefixes); c) the presence of synonyms for non-derivative verbs, which leads to synonymous competition.

The category of location is related to the individual's perception of the world, spatial characteristics, and their reflection on the speech, which predetermines the interest of locative relations. Locative verbs form the core of the verbal means reflecting spatial relations. The study of locative verbs in German and Ukrainian is slightly different. So, in Ukrainian, locative verbs are considered in terms of the word-formation (Gorpinich, 1998; Vihovonec', 1988; Voznij, 1981). In German, locative verbs are studied in terms of the semantic structure (Ballmer and Brennstuhl, 1986; Maienborn, 1990), typological realization of the location (Newman, 2002; Ameka and Levinson, 2007; Hess, 2007), their valence and syntactic features (Gerling and Orthen, 1979; Wunderlich, 1985; Kaufmann, 1989 and 1995; Stupak, 2010).

In the broad sense, locative verbs include verbs of motion as well as positional verbs (Kaufmann, 1995: 56; Krassin, 1984: 98-100; Leisi, 1975: 44; Talmy, 1985: 61). There are approaches that differentiate the concept of motion and location (Maienborn, 1990: 121-122; Wunderlich and Herweg, 1991: 759-762; Schröder, 1983: 214; Steinitz, 1998: 307; Talmy, 1985: 6061). Thus, verbs of motion (Obergruppe der Bewegungsverben) indicate a way of changing the location and denote "chaotic" motion; verbs of location (Fortbewegungsverben) indicate a certain direction of the motion considering a definite point (Maienborn 1996: 25).

According to this definition, verbs of location are characterized by four structural elements, namely: the starting point, destination, route and direction. Since the distinction between motion and location for this study is essential, within the framework of the current research, locative derived 
causative verbs include the verbs of location, the semantics of which indicates the location of a particular place, movement of an object to a certain place or from one place to another.

Consequently, if the verbs of location describe the spatial movement, then the positional verbs identify the particular type of position of individuals or objects regarding other objects, as well as in space (inside, on the surface, etc.). There are a number of alternative terms with similar or overlapping semantics in the literature, which include 'posture verbs' or 'verbs of posture', 'positionals' or 'verbs of body position' and 'verbs of spatial configuration' (Talmy, 1985: 65; Serra Borneto, 1996: 29; Newman, 2002: 65; Levinson and Maienborn, 1996: 15-16; Atintono, 2013: 25). Newman (2002) uses posture verbs because the contributor focuses on human posture while Ameka and Levinson (2007) also apply posture and positional verbs as two classes of locative verbs. Within the current research positional verbs include both posture and positional verbs in the German and Ukrainian languages. Although positional verbs have been described in many languages (Ameka and Levinson, 2007; Newman, 2002; Serra Borneto, 1996), their semantic features have never been previously explored thoroughly in German and Ukrainian as far as the literature shows. The case of German and Ukrainian positional derived causative verbs was chosen to show how typologically different languages, on the one hand, have similarity in expressing the basic concepts of positional causative situation. But on the other hand, they differ in the spatial representation.

\section{CORPUS AND METHODOLOGY: THE PROBLEM OUTLINED}

The semantic category of the causation can be expressed within different levels of the language system; however, the main lexical means of causation are causative verbs, the interpretation of which is characterized by a contradiction $^{1}$. Generally, linguists identify causative verbs as the transitive ones with the meaning to transform into such a state or cause an action expressed by a corresponding verb stem (Abusch, 1986: 59; Persson, 1975: 76; Wunderlich, 1997: 28; Zimmer, 1976).

In this study, the criterion for revealing the lexical base and the derived causative verb is the structural and semantic motivation ${ }^{2}$. The following structural-semantic relations between the derived causative verb and the root word can be:

\footnotetext{
1 There are different views regarding the content of the functional semantic class of the causative verbs. For example, some scholars assume causative verbs as the verbs in which the caused event is expressed by the infinitive, for example: 'to ask to help', where 'to ask' $\rightarrow$ a causative verb, 'to help' $\rightarrow$ the effected predicate (Comrie, 1976; Shibatani, 1964).

2 Despite the fact that the problem of derivation process was studied by many linguists (Ehrich, 1992; Erben, 1993: 101; Hinderling, 1982; Kühnhold, 1973; Wellmann, 1973), there is still no criterion concerning the difference of the studied phenomena.
} 
1) the derived causative verb is semantically motivated by the stem. The semantic motivation reveals that the meaning of the stem is the basis of the lexical meaning of the derivative (Erben, 1993: 27-28 and 31-32; Stupak, 2016).

2) morphological the derivative is more complex than the stem. This means that the derivative combines the stem and those structural, structural-semantic and other elements, by means of which it is formed.

3) the whole morphemic structure of the stem should not necessarily be included in the structure of the derivative (Wellmann, 1973: 23-78; Erben, 1993: 90-91).

4) the derivative and the stem refer to the different thematic class ${ }^{3}$.

In Ukrainian, verbs can merge into the pairs according to the aspect, for example, pidvishuvati 'to put something into the hanging position' (the imperfective aspect) and pidvisiti 'to have put something into the hanging position' (the perfect aspect). Within the framework of the current research, the class pair is assumed as the one, whose components differ only in the grammatical category of the class in case of the absolute identity of the lexical meaning. Thus, the verbs pidvishuvati and pidvisiti oppose each other by the aspect.

Unlike the form-formation, in case of the word-formation there is a simultaneous change of the aspect and lexical meaning of the positional derived causative verb, for example, hiliti 'to change the direct position of something into inclined' (the imperfective aspect) $\rightarrow$ prihiliti 'to cause to be very near' (the perfect aspect).This example shows that the prefix pri- does not only differentiate the aspect (gives it a perfect form), but also gives the derived causative verb prihiliti an additional semantic meaning 'tight'. In such cases, the derivative is included in the general corpus of positional derived causative verbs, and the verb prihiliti acts as a correlate of the perfect aspect, formed from the verb of the indefinite aspect hiliti according to the rules of aspect formation.

A notable milestone in the development of the theory of causality was the work of the Leningrad Typological Group, a collective monograph "Typology of causative constructions" (Nedyalkov and Silnitsky,1969), with the release of which denotative approach in the interpretation of the concepts of causative construction is dominated. The denotative approach is based on the concept of causative situation that consists of two micro-situations: the causal microsituation is called antecedent and the causative microsituation is called consequent (Nedyalkov and Silnitsky, 1969: 6).

Based on the denotative approach, within the current research causative verbs are considered to express at least two situations: antecedent and consequent. Consequently, in the present research positional causative verbs are characterized by the corresponding types of antecedent-consequent correlation:

\footnotetext{
3 In these cases, there is a change of domain (Comrie and Polinsky, 1993) or, according to alternative terminology, it is the change of the thematic class (Kutscher, 2009).
} 
a) the presence of the causative meaning and the absence of the corresponding non-causative correlate, $c f:$ dehnen 'to stretch in length'; gnati 'to force to move in a certain direction'4.

b) the correlation of the causative and non-causative meanings (morphological way of formation), cf:: sitzen 'to be in the sitting position' $\rightarrow$ setzen 'to make someone sit'; visiti 'to be in the hanging position' $\rightarrow$ vishati 'to put something into the hanging position'.

c) the context-syntactic relations (syntagmatic way of formation), that is, the verb contains the causative and non-causative meanings, the implementation of which depends on the context: hängen 'to be in the hanging position' and 'to cause to put something into the hanging position':

(1) (a) ... und ich meinen Mantel an den Kleiderhaken hängte...

'... I hung my coat on the hanger ...' (Böll, 1998: 102).

(b) Das Bild hängt an der Wand.

'Picture is hanging on the wall'.

The verb hängen in example (1a) functions as causative with the meaning 'to put something into the hanging position'; in the example (1b) hängen implements the non-causative meaning of 'to be in the hanging position'.

The description of semantics is characterized by two approaches:

- Semasiological, coming from a sign (lexeme) towards its meaning and the signified object (Bierwisch, 1983: 65; Brekle, 1972: 68; Fleischer, 1971; Zifonun, 1973: 161).

- Onomasiological, coming from the object towards its name (Glinz, 1962: 132;

Kaliuščenko, 1988: 32; Storch, 1978: 34; Weisgerber, 1962: 235).

To classify the semantic types of the derived causative verbs, an onomasiological approach is applied. According to this approach, verbs with different affixes are grouped together into the semantic classes on the basis of the semantic features of the consequent identity (causative action). Within each semantic class, the groups are distinguished based on the paraphrases or the definition of the derived verb by the synonymous expression, which includes a stem and a verb or a verbal group ${ }^{5}$. The definition in this case is translated by the semantic language and is given by means of an interpretation formula (Kühnhold, 1973; Storch, 1978: 56; Stiebels, 1996: 45; Stupak, 2018: 432).

The semantic description of derived causative verbs is based on componential analysis, which provides a descriptive model for semantic content. Taking into account that the meaning of a verb can be characterized by the restricted set of semantic components (Geeraerts, 2010: 80), the derived causative verb can include such components as the causer (X); consequent

\footnotetext{
${ }^{4}$ Such verbs are called lexical causatives, i.e. verbs that are discernibly semantically causatives, but are not formally analyzable into two morphemes (Kemmer and Verhagen, 1994: 118).

${ }^{5}$ Such syntactic constructions in the linguistic literature are called paraphrases or periphrases (Kaliuščenko, 1998: 47), syntactic paraphrases (Barz, 1988: 66), transformation meanings (Wellmann, 1973: 74).
} 
(V) and causee $(\mathrm{Y})$. Thus, the interpretation formula of the positional causative verb "X action V cause causes $\mathrm{Y}$ to be in a positional V" includes the obligatory elements of the causative situation. Therefore, based on the semantics of the consequent, the positional derived causative verbs express an action that causes the causee $(\mathrm{Y})$ to get a position Posit.

To describe the semantic structure of the causative constructions, the following interpretation formula is used " $\mathrm{X}$ action $\mathrm{V}$ cause causes $\mathrm{Y}$ to perform an action $\mathrm{V}^{\prime}$, where the causer $\mathrm{X}$ corresponds to the following semantic roles: 1) agent (Ag), if this is the person that creates the situation; 2) causes (Cause) $\rightarrow$ the object or phenomenon that creates the situation; the causee $Y$ is characterized by a wider set of semantic roles: 1) patient (Pat) $\rightarrow$ is an individual undergoing the action of the agent; 2) the object (Ob) is an inanimate object undergoing the action of the causee; 3) consequent (V) has the semantic role of a position Posit.

The data collected for the study is based on the vocabulary and fiction texts of German and Ukrainian. Each type of data has its contribution to the study of the positional derived causative verbs. The frequency of these verbs, the semantics, syntax, statistics, and the examples of their usage are obtained through the DWDS main corpus (DWDS-Kernkorpus) for German and Mova.info corpus for Ukrainian.

The corpus of the positional derived causative verbs is fully used to carry out their structural classification in German and Ukrainian, to determine the word classes of stems, to identify the common and distinctive features in the studied languages. The data obtained is used for a semantic-syntactic analysis in order to identify the patterns and tendencies of use of the derived causative verbs, as well as to establish their common and distinctive features in the German and Ukrainian languages.

We pose the following research question: How the meaning of positional derived causative verbs correlates with the structure of German and Ukrainian? The study of positional derived causative verbs crosslinguistically views the differences and similarities in lexical semantic structure and the relationship of lexical meaning to syntax. In this regard, the following issues are discussed:

- To determine the definition of positional causative verbs.

- To establish the derived capacity of the causative positional verbs' formation within both languages.

- To describe the semantic models of the causative positional verbs in German and Ukrainian.

- To establish the semantic features expressing the components of the positional causative situation in both languages.

- To reveal the gaps while transferring the individual spatial meanings of the causatives in German and Ukrainian. 


\section{GENERAL CHARACTERISTICS OF THE POSITIONAL CAUSATIVE VERBS IN THE GENERAL AND UKRAINIAN LANGUAGES}

The majority of positional causative verbs are derived from verbs; however, they may be also derived from adjectives only in German and from adverbs only in Ukrainian (see Table 1).

\begin{tabular}{|c|c|c|c|c|c|c|c|c|}
\hline \multirow{3}{*}{$\begin{array}{l}\text { Semantic sub- } \\
\text { classes of } \\
\text { positional de- } \\
\text { rived causa- } \\
\text { tive verbs }\end{array}$} & \multicolumn{6}{|c|}{ Word classes of stems } & \multirow{2}{*}{\multicolumn{2}{|c|}{ Total }} \\
\hline & \multicolumn{2}{|c|}{ Verb } & \multicolumn{2}{|c|}{ Adjective } & \multicolumn{2}{|c|}{ Adverb } & & \\
\hline & German & Ukrainian & German & Ukrainian & German & Ukrainian & German & Ukrainian \\
\hline $\begin{array}{l}\text { get into a posi- } \\
\text { tional }\end{array}$ & $\begin{array}{c}10 \\
(2.9 \%)\end{array}$ & $\begin{array}{c}24 \\
(10.5 \%)\end{array}$ & - & - & - & & $\begin{array}{c}10 \\
(2.9 \%)\end{array}$ & $\begin{array}{c}24 \\
(10.5 \%)\end{array}$ \\
\hline up/down & $\begin{array}{c}51 \\
(15.0 \%)\end{array}$ & $\begin{array}{c}27 \\
(11.8 \%)\end{array}$ & - & - & - & - & $\begin{array}{c}51 \\
(15.0 \%)\end{array}$ & $\begin{array}{c}27 \\
(11.8 \%)\end{array}$ \\
\hline on the surface & $\begin{array}{c}43 \\
(12.7 \%)\end{array}$ & - & - & - & - & - & $\begin{array}{c}43 \\
(12.7 \%)\end{array}$ & - \\
\hline within/among & $\begin{array}{c}59 \\
(17.4 \%)\end{array}$ & $\begin{array}{c}38 \\
(16.7 \%)\end{array}$ & - & - & - & - & $\begin{array}{c}59 \\
(17.4 \%)\end{array}$ & $\begin{array}{c}38 \\
(16.7 \%)\end{array}$ \\
\hline $\begin{array}{l}\text { under the ob- } \\
\text { ject }\end{array}$ & $\begin{array}{c}41 \\
(12.1 \%)\end{array}$ & $\begin{array}{c}29 \\
(12.7 \%)\end{array}$ & - & - & - & - & $\begin{array}{c}41 \\
(12.1 \%)\end{array}$ & $\begin{array}{c}29 \\
(12.7 \%)\end{array}$ \\
\hline near/far away & $\begin{array}{c}81 \\
(23.9 \%)\end{array}$ & $\begin{array}{c}57 \\
(25.0 \%)\end{array}$ & $\begin{array}{c}4 \\
(1.2 \%)\end{array}$ & - & - & $\begin{array}{c}5 \\
(2.2 \%)\end{array}$ & $\begin{array}{c}85 \\
(25.1 \%)\end{array}$ & $\begin{array}{c}62 \\
(27.2 \%)\end{array}$ \\
\hline $\begin{array}{c}\text { forward/back- } \\
\text { ward }\end{array}$ & $\begin{array}{c}39 \\
(11.5 \%)\end{array}$ & - & - & - & - & - & $\begin{array}{c}39 \\
(11.5 \%)\end{array}$ & - \\
\hline graduality & $\begin{array}{c}4 \\
(1.2 \%)\end{array}$ & $\begin{array}{c}9 \\
(3.8 \%)\end{array}$ & - & - & - & - & $\begin{array}{c}4 \\
(1.2 \%)\end{array}$ & $\begin{array}{c}9 \\
(3.8 \%)\end{array}$ \\
\hline $\begin{array}{c}\text { mode of causa- } \\
\text { tion }\end{array}$ & $\begin{array}{c}7 \\
(2.1 \%)\end{array}$ & $\begin{array}{c}39 \\
(17.1 \%)\end{array}$ & - & - & - & - & $\begin{array}{c}7 \\
(2.1 \%)\end{array}$ & $\begin{array}{c}39 \\
(17.1 \%)\end{array}$ \\
\hline Total & $\begin{array}{c}335 \\
(98.8 \%)\end{array}$ & $\begin{array}{c}223 \\
(97.8 \%)\end{array}$ & $\begin{array}{c}4 \\
(1.2 \%)\end{array}$ & - & - & $\begin{array}{c}5 \\
(2.2 \%)\end{array}$ & $\begin{array}{c}339 \\
(100 \%)\end{array}$ & $\begin{array}{c}228 \\
(100 \%)\end{array}$ \\
\hline
\end{tabular}

Table 1: The semantic classification of positional derived causative verbs in German and Ukrainian

Table 1 presents the total number of positional derived causative verbs according to their rate of occurrences within German and Ukrainian corpora, including both the word classes of stems and the corresponding semantic interpretation. The classification is based on the semantics containing the verbs which describe: resulting body position of the Causee (lying/sitting/standing/leaning); elevation of the Causee (up/down); the position of the Causee to a point (on/under/within/among/forward/backward); the graduality of elevation of the Ground or Agent and the Causee (higher/lower); the mode of causation; relative distance between the Causee 
and the Agent (near/far away). Positional derived causative verbs cover a broader semantic range and can be grouped into seven positional semantic subclasses identified in the German language (see Table 1). Yet, in Ukrainian positional derived causative verbs can be grouped only into five semantic subclasses, as Table 1 shows.

\subsection{POSITIONAL DERIVED CAUSATIVE VERBS WITH THE MEANING 'TO CAUSE TO PUT INTO A BODY POSITION'}

Table 1 demonstrates that positional derived causative verbs with the meaning 'to cause to put into a body position' are not widespread in both languages, $c f$. : German $\rightarrow 2.9 \%$, Ukrainian $\rightarrow 10.5 \%$. In both languages they are derived from non-causative verbs, denoting a sitting/hanging/standing position (see (1 (a), (b)) and by means of prefixes pri-, pid-in Ukrainian (see (1c)). It should be noticed that in both languages the morphological derivation (see (1 (a), (b)) of a causative from non-causative verb was prevailed in Indo-European, though it is not widespread in modern languages.

(1) (a) liegen 'to be in the lying position' $\rightarrow$ legen 'to put into the lying position', sitzen 'to be in the sitting position' $\rightarrow$ setzen 'to put into the sitting position', stehen 'to be in the standing position' $\rightarrow$ stellen 'to put into the standing position'. (b) siditi 'to be in the sitting position' $\rightarrow$ sadzhati 'to put into the sitting position', stoyati 'to be in the standing position' $\rightarrow$ staviti 'to put into the standing position', visiti 'to be in the hanging position' $\rightarrow$ vishati 'to put into the hanging position'.

(c) vishati 'to put into the hanging position' $\rightarrow$ privishuvati, pidvishuvati 'to put into the higher hanging position'.

There is no change in the thematic class of positional derived causative verbs with the meaning 'to cause to put into a body position or positional' in both languages. The positional derived causative verb characterizes a locative situation in which an agent puts another object into spatial or body position. It can be described by the interpretation formula "X causes $Y$ to get a certain position Posit", where the causer X corresponds to the semantic role of Ag; Vcause is presented by a positional derived causative verb; the causee $\mathrm{Y}$ coincides with the semantic Ob; Posit (spatial or body position) is incorporated in the meaning of the base word, from which positional causative derived verb is formed.

Positional derived causative verbs with the meaning 'to cause to put into a body position' describe the situation presented by the semantic model AgVcause-Ob-Posit:

(2) Zosya pidvisila kolisku na vervechkah, shchob Bonifacij zakolihav.

(Ag) (V cause-Posit) (Ob)

Zosya hung a cradle on the strings to make Bonifacio lull the baby.

(Zemljak, 2002: 191) 
The sentence in (2) describes a situation in which the causee Ob kolisku 'cradle' is directly under the agent's authority. So, Ag Zosya put Ob kolisku into the higher hanging position, which is expressed by the meaning of the stem verb visila 'to be in the hanging position', from which the positional causative verb pidvisila is derived.

As stated in Table 2, such causative situation takes place in both languages (5.8\% in German and 6.9\% in Ukrainian).

\begin{tabular}{|c|c|c|c|c|c|c|c|c|c|c|c|c|}
\hline \multirow{3}{*}{$\begin{array}{c}\text { Semantic } \\
\text { subclasses } \\
\text { of } \\
\text { positional } \\
\text { derived } \\
\text { causative } \\
\text { verbs }\end{array}$} & \multicolumn{12}{|c|}{ Semantic models of positional derived causative verbs } \\
\hline & \multicolumn{2}{|c|}{$\begin{array}{l}\text { Ag-Vcause-Ob- } \\
\text { Posit-Orient }\end{array}$} & \multicolumn{2}{|c|}{$\begin{array}{c}\text { Ag-Vcause-Ob- } \\
\text { Posit }\end{array}$} & \multicolumn{2}{|c|}{$\begin{array}{l}\text { Ag-Vcause-Pat- } \\
\text { Posit-Orient }\end{array}$} & \multicolumn{2}{|c|}{$\begin{array}{l}\text { Ag-Mode- } \\
\text { Vcause-Pat- } \\
\text { Posit-Orient }\end{array}$} & \multicolumn{2}{|c|}{$\begin{array}{l}\text { Ag-Mode- } \\
\text { Vcause Ob- } \\
\text { Posit }\end{array}$} & \multicolumn{2}{|c|}{ Total } \\
\hline & $\begin{array}{c}\text { Germ. } \\
(\%)\end{array}$ & $\begin{array}{c}\text { Ukrain } \\
(\%)\end{array}$ & $\underset{(\%)}{\text { Germ. }}$ & $\begin{array}{l}\text { Ukrain } \\
(\%)\end{array}$ & $\underset{(\%)}{\text { Germ. }}$ & $\begin{array}{c}\text { Ukrain } \\
(\%)\end{array}$ & $\underset{(\%)}{\text { Germ. }}$ & $\begin{array}{c}\text { Ukrain } \\
(\%)\end{array}$ & $\underset{(\%)}{\text { Germ. }}$ & $\begin{array}{l}\text { Ukrain } \\
(\%)\end{array}$ & $\underset{(\%)}{\text { Germ. }}$ & $\begin{array}{c}\text { Ukrain. } \\
(\%)\end{array}$ \\
\hline $\begin{array}{l}\text { get into a } \\
\text { position }\end{array}$ & - & - & $\begin{array}{c}35 \\
(5.8)\end{array}$ & $\begin{array}{c}47 \\
(5.6)\end{array}$ & - & - & - & - & - & $\begin{array}{c}11 \\
(1.3)\end{array}$ & $\begin{array}{c}35 \\
(5.8)\end{array}$ & $\begin{array}{c}58 \\
(6.9)\end{array}$ \\
\hline up/down & - & - & $\begin{array}{l}60 \\
(9.9)\end{array}$ & $\begin{array}{c}76 \\
(9.0)\end{array}$ & - & - & - & - & - & $\begin{array}{c}34 \\
(4.0)\end{array}$ & $\begin{array}{l}60 \\
(9.9)\end{array}$ & $\begin{array}{c}110 \\
(13.0)\end{array}$ \\
\hline $\begin{array}{l}\text { on the sur- } \\
\text { face }\end{array}$ & $\begin{array}{c}64 \\
(10.5)\end{array}$ & - & - & - & - & - & - & - & - & - & $\begin{array}{c}64 \\
(10.5)\end{array}$ & - \\
\hline $\begin{array}{l}\text { inside/ } \\
\text { among }\end{array}$ & $\begin{array}{c}107 \\
(17.6)\end{array}$ & $\begin{array}{c}149 \\
(17.6)\end{array}$ & - & - & - & - & - & - & - & - & $\begin{array}{c}107 \\
(17.6)\end{array}$ & $\begin{array}{c}149 \\
(17.6)\end{array}$ \\
\hline $\begin{array}{c}\text { under the } \\
\text { object }\end{array}$ & $\begin{array}{c}35 \\
(5.8)\end{array}$ & $\begin{array}{c}104 \\
(12.3)\end{array}$ & - & - & - & - & - & - & - & - & $\begin{array}{c}35 \\
(5.8)\end{array}$ & $\begin{array}{c}104 \\
(12.3)\end{array}$ \\
\hline $\begin{array}{l}\text { near/far } \\
\text { away }\end{array}$ & $\begin{array}{c}149 \\
(24.5)\end{array}$ & $\begin{array}{l}83 \\
(9.8)\end{array}$ & - & - & $\begin{array}{c}81 \\
(13.3)\end{array}$ & $\begin{array}{c}143 \\
(16.9)\end{array}$ & $\begin{array}{c}19 \\
(3.1)\end{array}$ & $\begin{array}{c}231 \\
(27.3)\end{array}$ & - & - & $\begin{array}{c}249 \\
(41.0)\end{array}$ & $\begin{array}{c}399 \\
(47.2)\end{array}$ \\
\hline $\begin{array}{c}\text { for- } \\
\text { ward/back } \\
\text { ward }\end{array}$ & - & - & $\begin{array}{c}38 \\
(6.3)\end{array}$ & - & - & - & - & - & - & - & $\begin{array}{l}38 \\
(6.3)\end{array}$ & - \\
\hline graduality & - & - & $\begin{array}{c}19 \\
(3.1)\end{array}$ & - & - & - & - & - & - & $\begin{array}{c}26 \\
(3.1)\end{array}$ & $\begin{array}{c}19 \\
(3.1)\end{array}$ & $\begin{array}{c}26 \\
(3.1)\end{array}$ \\
\hline Total & $\begin{array}{c}355 \\
(58.5)\end{array}$ & $\begin{array}{c}336 \\
(39.7)\end{array}$ & $\begin{array}{c}152 \\
(25.1)\end{array}$ & $\begin{array}{c}123 \\
(14.6)\end{array}$ & $\begin{array}{c}81 \\
(13.3)\end{array}$ & $\begin{array}{c}143 \\
(16.9)\end{array}$ & $\begin{array}{c}19 \\
(3.1)\end{array}$ & $\begin{array}{c}231 \\
(27.3)\end{array}$ & - & $\begin{array}{c}71 \\
(8.4)\end{array}$ & $\begin{array}{c}607 \\
(100)\end{array}$ & $\begin{array}{c}846 \\
(100)\end{array}$ \\
\hline $\begin{array}{l}\text { Place by } \\
\text { frequency }\end{array}$ & I & I & II & IV & III & III & IV & II & - & $\mathrm{V}$ & & \\
\hline
\end{tabular}

Table 2: The semantic models of positional causative verbs in the German and Ukrainian languages

\subsection{POSITIONAL DERIVED CAUSATIVE VERBS WITH THE MEANING 'TO CAUSE TO GET INTO THE SPATIAL POSITION UP/DOWN'}

The positional derived causative verbs with the meaning 'to cause to get into the spatial position up/down' occur in both languages (see Table 2). In German, positional derived causative verbs with this meaning include compound verbs with the adjective as the first component (see (3(a)), as well as 
the prefixed deverbal causatives. These prefixes correlate with the basic spatial meanings of the corresponding prepositions (see 3(b)-(e)). In German, the spatial meanings 'up/down' are realized using the prefixes auf-, er-, nieder- (see (3(b)). Occasionally, examples of positional derived causative verbs with the extra feature 'graduality' were revealed (see (3(c)).

(3) (a) hoch 'high', klappen 'to lift' $\rightarrow$ hochklappen 'to lift up'.

(b) heben 'to lift' $\rightarrow$ aufheben, erheben ' to lift up',

zwingen 'to force' $\rightarrow$ niederzwingen 'to force smb or smth to be down'.

(c) heben 'to raise' $\rightarrow$ anheben 'to raise a little higher'.

In Ukrainian, the positional derived causative verbs with the meaning 'to cause to get into the spatial position up/down' include prefixed verbs, which correlate with the basic spatial meanings of the corresponding prepositions (see (4)). The spatial meanings 'up/down' are realized using prefixes $z a-(z-)$, $o-$, pid- (see (4a). The specificity of the prefix $z a$-contributes the implementation of two opposite directions 'up/down'. In Ukrainian, unlike German, positional derived causative verbs realize two additional meanings, 'mode' and 'graduality', simultaneously (see (4b)). Thus, the positional derived causative verb pidsmikati is formed from the verb of motion smikati 'to pull', which specifies the method of causation (pulling), and the prefix pid-modifies the additional meaning 'higher'. Likewise, positional derived causative verbs with the meaning of 'to cause to get into the spatial position up/down in a manner called by motivation verb' is revealed. The derivatives analyzed are formed using the prefixes $s^{-}, z^{-}\left(i z^{-}\right)$(see (4c)).

(4) (a) vishati 'to put into the hanging position' $\rightarrow$ zvishuvati 'to force to lower down, leaving in a hanging position', puskati 'to set in motion' $\rightarrow$ zapuskati 'to force to fly up', puskati 'to set in motion' $\rightarrow$ opuskati 'to force to move down'.

(b) smikati 'to pull' $\rightarrow$ pidsmikati ' to lift a bit higher by pulling smth'.

(c) kotiti 'to roll' $\rightarrow$ skotiti 'to get down by rolling smth'; voditi 'to lead' $\rightarrow$ zvoditi 'to force someone to go down along with smb'.

According to the data, in German the change of the thematic class of the verb-stem represents $15 \%$. Such transformation occurs in positional causative verbs with the meaning 'to cause to get into the spatial position up/down' derived from the verbs of motion. In Ukrainian, the change of the thematic class takes place in $57 \%$ from the verbs of motion (see (4b), (4e)) and action (see (4a)).

Positional derived causative verbs with the meaning 'to cause to get into the spatial position up/down' are described by the interpretation formula "X by the action Vcause causes $Y$ to get a certain position Posit in space". The spatial position Posit is indicated by the semantics of the derivational prefix in both languages and by the adjective as the first component only in the German language. 
Such causative situation of getting into the position 'up/down' is presented by the semantic model Ag-Vcause-Ob-Posit (see (5a)) or Ag-ModeVcause-Ob-Posit (see (5b)). In (5a) the compound positional causative derived verb hochschlagen 'to lift up' consists of the first component - the adjective hoch 'up', which specifies the position in space, and the verb schlagen 'to beat'. The semantic model Ag-Mode-Vcause-Ob-Posit is typical of positional causative verbs derived from the verbs of motion and action. The additional semantic role of Mode is indicated by the meaning of the verb-stem and used in positional derived causative verbs with the meaning in a way defined by the stem, to cause to get into a position in space' (see (5b)). The sentence in (5b) describes a situation in which the causer Ag (vin 'He') in a way of causation (Mode), which is expressed by the meaning of the motivation verb kotiti 'to roll', causes the $\mathrm{Ob}$ (dizhku 'a tub') to be in the caused position Posit (down). The causer's way of causation (Mode) is expressed by the meaning of the stem-verb kotiti 'to roll' and the spatial position 'down' is pointed by the semantics of the derivational prefix s-.

(5) (a) Ich schlage den Mantelkragen hoch und (...)

'I lifted the collar of my coat and (...)'

(b) Vin ckotiv dizhku, tam chekala na n'ogo Otchenashka.

(Becker 1981: 78)

Ag Mode - Vcause - Posit Ob

'He rolled down a tub, where Otchenashka was waiting for him'.

(Zemljak 2002: 68)

\subsection{POSITIONAL DERIVED CAUSATIVE VERBS WITH THE MEANING 'TO CAUSE TO GET INTO THE POSITION AS FOR A POINT'}

This semantic subclass of positional verbs includes causative verbs derived by means of prefixes with the spatial meanings 'forward/backward', 'on/under', 'within/among' and takes place in both languages (see Table 2).

In German, positional causative verbs with the partial meaning 'to cause to get into the position as for a point' include prefixed derivatives with the meanings 'on the surface', 'inside/among', 'under the object', and the compound verbs with the first component $\rightarrow$ the adverb: hinaus 'outside, in the direction from the speaker', heraus 'outside, in the direction towards the speaker' (see (6a)).

The spatial meanings 'on/under' are expressed by the prefixes auf-, über-, unter-, nieder- (see (6b)). However, in Ukrainian, the spatial meaning 'on' is realized using the preposition $n a$ 'on', and prefix $n a$-means 'to attach to something'. In this regard, there are no positional causative verbs with the meaning 'to cause to be on the surface' in Ukrainian.

In German, the spatial meaning 'inside' is typical of positional causative verbs, derived from verbs with the prefix ein- (see (6c)). In contrast to Ukrainian, the meanings 'forward/backward' are fixed in German prefixes vor-, zurück- (see $(6 d))$. In Ukrainian the corresponding meanings are realized by 
combining the verb and the adverb postaviti + vpered/nazad 'to put + forward/backward' because of the absence of the corresponding spatial prefixes.

(6) (a) heben 'to lift' $\rightarrow$ hinausheben 'to force to lift up, in the direction from the speaker',

hängen 'to hang' $\rightarrow$ heraushängen 'to force to hang out, in the direction towards the speaker'.

(b) setzen 'to put' $\rightarrow$ aufsetzen 'to force smth to lay on', legen 'to put' $\rightarrow$ überlegen 'to force smth to be on smth', legen 'to put' $\rightarrow$ unterlegen 'to force to put smth under smth', ziehen 'to pull' $\rightarrow$ niederziehen 'to force to pull smth under smth'.

(c) bauen 'to build' $\rightarrow$ einbauen 'to force to be built-in', schieben 'to move' $\rightarrow$ einschieben ' to force to put in'.

(d) stellen 'to place' $\rightarrow$ vorstellen 'to force smb or smth to be forward', legen 'to lay' $\rightarrow$ zurücklegen 'to force to put back'.

In Ukrainian, positional causative verbs with the spatial meaning 'to cause to get into the position as for the point' include prefixed derivatives with the meanings 'under', 'inside' (see Table 1). The spatial meaning 'under' is presented by the prefix pid-, based on the meaning of the corresponding preposition pid 'under' (see (7a)). The spatial meaning 'inside' is realized by the prefixes $v$-, $u$-, $u v i-, v v i-(\operatorname{see}(7 \mathrm{~b}))$.

(7) (a) steliti 'to lay' $\rightarrow$ pidsteliti 'to force to put something under someone, something'.

(b) pihati 'to pull' $\rightarrow$ upihati, vpihati 'pulling, to poke something inside something', sadzhati 'to thrust' $\rightarrow$ vsaditi 'to force to thrust something inside something'.

As it can be seen from Table 2, in German, only 6\% of positional causative verbs are derived from verbs of motion. In Ukrainian, they make up 39\% and can be derived not only from verbs of motion, but also from verbs of process.

The meaning of positional causative verbs 'to cause to get into the position as for a point' implies the additional semantic role of Orient, which is expressed by individuals or objects. The situation presented by the semantic model Ag-Vcause-Ob-Posit-Orient is typical in both languages (see Table 2).

In (8) the positional causative verb unterstellen 'to force to be under something' is formed by the prefix unter- 'under' with the corresponding spatial meaning which implies the caused position unter- 'under' as for the point das Buch 'a book'. The sentence in (8) describes a situation in which Ag (sie 'she') causes Ob (den Zettel 'a note') to be in the caused position Posit (unter 'under') as to Orient (das Buch 'a book').

(8) Sie schaut mich erschrocken an, dann stellt sie den Zettel das Buch unter.

'She looks at me scared, then puts a note under a book'. 


\subsection{POSitional deRIVEd CAUSATIVe Verbs With THE MEANING 'TO CAUSE TO Be IN A DISTANCE FROM THE POINT'}

Positional derived causative verbs of this subclass are widespread in both languages, as Table 2 illustrates. German positional causative verbs with this meaning include deverbal prefixed derivatives (with the prefixes an-, mit-, weg-) (see (9a)), compound verbs with the first component, the adjective nahe 'close' (see (9b)) and deadjectival verbs with the meaning to cause to be in a distance indicated by an adjective' (see (9c)).

(9) (a) lehnen 'to lean' $\rightarrow$ anlehnen 'to force to put something very close to someone', stellen 'to put' $\rightarrow$ anstellen 'to force to put something close to something',

halten 'to keep' $\rightarrow$ weghalten 'to force to keep something away from someone'.

(b) legen 'to put' $\rightarrow$ nahehlegen 'to close, to force to put close to something, someone'.

(c) nahe 'to close' $\rightarrow$ nähern to cause to approach'.

In Ukrainian, the spatial meaning 'far away/near' is realized using the prefixes vid-, pid-, pri-, which denote the distance/approach to the object. Positional causative verbs are derived from verbs of motion and action indicating the method of causation. They have the meaning in a way called by verb-stem, to cause to be in a distance from the point' (see (10(a)). Although positional causative verbs derived from the verbs of process by means of the prefix pri-do not indicate the mode of causation (see $(10(\mathrm{~b}))$.

(10) (a) shtovhati 'to push' $\rightarrow$ vidshtovhati 'pushing, push away', tyagnuti 'to pull' $\rightarrow$ pidtyagnuti 'pulling, approaching someone, smth', kotiti 'to roll' $\rightarrow$ pidkotiti 'rolling, approaching someone, smth'.

(b) maniti 'to beckon' $\rightarrow$ primanyuvati 'to force to approach', staviti 'to force to get into the standing positional' $\rightarrow$ pristavlyati 'to put smth close to smth'.

Positional derived causative verbs with the meaning 'to cause to be away from the point' are revealed in German in $41.0 \%$; in Ukrainian $\rightarrow 47.2 \%$ (see Table 2). The peculiarity of the derivatives is that the object of causation corresponds to the semantic roles of Orient and Ob. For the participant Orient the meaning of animate/inanimate is irrelevant, so in both cases it has the same marking. Thus, the semantic models Ag-Vcause-Ob-Posit-Orient (see examples (11a), (11b)) and Ag-Mode-Vcause-Pat-Posit-Orient (see (11c)) correspond to them. In (11a) the positional derived causative verb anziehen 'to force to pull to myself, the speaker' is formed by the prefix an-, which correlates with the meaning of the preposition an 'close'. The meaning of the derived causative verb anziehen implies that the semantic roles of $\mathrm{Ag}$ and Orient coincide. This situation, combining the semantic roles of Ag and Orient, is very common in German.

In Ukrainian as compared with German, the subject-subject relations are common and appear in the semantic models Ag-Vcause-Pat-Posit-Orient 
(see sentence (11b)) and Ag-Mode-Vcause-Pat -Posit-Orient (11c). The positional derived causative verb with the prefix pri-, i.d. prigortati 'to hold someone closely in one's arms' (see (11b)) correlates with the meaning of the preposition pri 'close'. Example (11b) reflects the situation in which Ag (Malva) causes Pat (hlopchika 'the boy') to get the position Posit 'close' as for Orient (do sebe 'to herself'). The semantic role Posit 'close' is expressed by the prefix pri- and the semantic role of Orient is realised by the combination of the preposition (do 'to') and the reflexive pronoun (sebe 'myself'), which is meant by Ag (Malva). In Ukrainian (11b) unlike German (11a), the semantic role Orient is expressed by a separate lexeme. In (11c) the positional derived causative verb vidshtovhuvati 'pushing, pulling away' is formed with the prefix vid-, the spatial meaning of which completely coincides with the meaning of the corresponding preposition vid 'from', which is used to determine the distance of an object from any place, subject, etc. Sentence (11c) presents the situation in which Ag (vona 'she') in the way of causation Mode (pushing) causes Pat (Mihajla 'Michael') to get Posit (far away) as for Orient (from herself). The semantic role of Posit 'away' is expressed by the meaning of the prefix vid-; the semantic role of Orient, which is realised by the combination of the preposition (vid 'from'), and the reflexive pronoun (sebe 'herself') coincide with the semantic role of Ag (vona 'she'). In common with (11a) the sentences in (11b) and in (11c) both contain the semantic roles of Ag and Orient, expressed by separate lexemes.

(11) (a) Ich ..., zog das Telefon $\underset{\text { Ag-Orient... vasit }}{\text { and }}$ und (...)

'I (...) pulled up the phone and (...)'

(b) Mal'va sudorozhno prigornula do sebe hlopchika.

(Böll 1985: 38)

Malva frantically embraced the boy.

(c) Vona grubo vidshtovhnula Mihajla vid sebe.
Ag.

(Ivanchuk 2006: 193)

She roughly pushed Michael away from herself.

(Matios 2007: 129)

\section{Conclusions}

The morphological analysis of the data revealed the predominance of common features by forming the positional derived causative verbs in German and Ukrainian. Deverbal positional causative verbs present in the majority of cases in both languages. Though, deadjectival causative verbs in German and deadverbal causative verbs in Ukrainian were isolated examples.

The prevalence of positional deverbal causative verbs in both languages resulted in a wide range of additional semantic features. The data indicated certain differences between two languages in representation of such semantic features as 'on', 'forward/backward' and 'mode of causation' (see 
Table 1). So, the absence of the prefixes with the spatial meaning "on the surface" in Ukrainian is realized by the preposition na 'on'; the spatial meaning "forward/backward" is implemented by the corresponding adverbs vpered 'forward' and nazad 'backward'. In Ukrainian, unlike German, the additional semantic meaning 'mode of causation' is more widespread. It can be realized within positional derived causative verbs separately or in combination with the other semantic features that specify the spatial position. It is possible because in Ukrainian the majority of positional derived causative verbs consist of the derivatives formed from verbs of motion and action.

The semantic diversity manifested by positional derived causative verbs exemplified the richness of the morphological means of German and Ukrainian. The functioning of positional derived causative verbs revealed the highest degree of completeness with the additional semantic information. Regarding the varieties of the extra features, the additional information of the consequent (lying/sitting/standing/leaning/up/down/on/under/within/ among/forward/backward/near/far away/higher/lower) is typical of German positional derived causative verbs. The characteristic of Ukrainian is the realization of the additional semantic features of both antecedent ('mode of causation') and consequent. It was found that German positional derived causative verbs are used to encode the consequent (the position) and are limited morphological resources for encoding the antecedent.

As the paper showed, the peculiarity of the semantic components of the positional causative situation is in the realization of the semantic role of Orient. The subject orientation of the semantic role Orient, which is determined by the location of Ag, is typical of German. Such a peculiarity of German is related to the availability and productivity of the prefixes of the hin-, her- and complex prefixes with the first component of herab-, herunter-and others, which implement the "category of subject orientation". However, in Ukrainian the semantic role of Orient is presented by a combination of a preposition with a noun, and has an abstract-spatial relationship, which can only be correlated with Ag within the context of the statement.

The positional derived causative verbs with the meaning "to cause to get a spatial position" are characterized by a range of semantic models: AgMode-Vcause-Ob-Posit, Ag-Vcause-Ob-Posit-Orient, Ag-Vcause-Pat-PositOrient, Ag-Mode-Vcause-Pat-Orient. Their variants depend on the partial meanings of the positional derived causative verbs of this group. The data showed that the subject-object relations are typical of positional derived causative verbs with the meaning "to cause to get a spatial position" in both languages under study.

However, the difference concerns the positional derived causative verbs with the partial meaning "to cause to be away from the point". Thus, for German the following features are discovered to be typical: the subject-object relations and the similarity of the semantic roles of Orient to Ag. In Ukrainian, as opposed to German, positional derived causative verbs are characterized by 1) interpersonal relations, 2) the expression of the semantic 
role of Orient as a separate lexeme, 3) the realization of the additional semantic role (Mode).

In other words, egocentric spatial representation is typical of German positional causative verbs. While Ukrainian causative verbs maintain caused body orientation and posture in relation to the surrounding environment. It was concluded that the features revealed of the locative relations in German and Ukrainian result in their specific structure. The data are consistent with the Sapir-Whorf hypothesis that the structure of a language affects cognitive processes of the speaker.

The revealed data can extend the study of lexical-morphological-syntactic expressions of causatives and locative constructions in cross-linguistically perspectives.

\section{REFERENCIAS}

ABUSCH, D. (1986): Verbs of Change, Causation, and Time. Center for the Study of Language and Information, Stanford University.

AMEKA, F. K. \& STEPHEN, L. C. (2007): "Introduction: the typology and semantics of locative predicates, posturals, positionals and other beasts", Linguistics, 45, pp. 847 871.

ATINTONO, A. S. (2013): The semantics and grammar of positional verbs in GURENE: a typological perspective. Accessed at: https://www.research.manchester.ac.uk (Award date: 01/08/2013).

BALLMER, TH. T. \& BRENNENSTUHL, W. (1986): Deutsche Verben. Eine Sprachanalytische Untersuchung des deutschen Verbwortschatzes Ergebnisse und Methoden moderner Sprachwissenschaft, Tübingen: Gunter Narr.

BARZ, I. (1988): Nomination durch Wortbildung, Leipzig: VEB Verlag Enzyklopädie.

BIERWISCH, M. (1983): "Formal and lexical semantics", Proc. of the XIIth International Congress of Linguists (Tokyo, August 29 - September 4), Tokyo/Gakushuin U.

BREKLE, H. (1972): Semantik. Eine Einführung in die sprachwissenschaftliche Bedeutungslehre, München: Fink.
COMRIE, B. \& POLINSKY, M. (1993): Causatives and transitivity. Studies in Language Companion Series (SLC). Amsterdam/Philadelphia: John Benjamins Company.

ERBEN, J. (1993): Einführung in die deutsche Wortbildungslehre (Grundlagen der Germanistik. B.17), Berlin: Erich Schmidt.

FLEISCHER, W. (1971): Wortbildung der deutschen Gegenwartssprache, Leipzig: Bibliographisches Inst.

GEERAERTS, D. (2010): Theories of Lexical Semantics, New York: Oxford University Press Inc.

GERLING, M. \& ORTHEN, N. (1979): Deutsche Zustands- und Bewegungsverben. Eine Untersuchung zu ihrer semantischen Struktur und Valenz, Tübingen: Narr.

GLINZ, H. (1962): Die innere Form des Deutschen, Bern/München.

GOLDBERG, A. (1995): Constructions: A Construction-Grammar Approach to Argument Structure, Chicago, London: The University of Chicago Press.

GORPINICH, V. O. (1998): Ukraïns'ka slovotuirna derivatologiya, Dnipropetrous'k: DDU.

HELBIG, G. (1971): Theoretische und praktische Aspekte eines Valenzmodelles, Halle: VEB Max Niemeyer Verlag.

HERRINGER, H. J. (1984): "Wortbildung: Sinn aus dem Chaos". Deutsche 
Sprache, $12 . \quad$ Düsseldorf: Schwann, S. 1-13.

HESS, K. (2007): Verb und Direktivum. Ein Beitrag zum Deutsch-Spanischen und Spanisch-Deutschen Sprachvergleich, Frankfurt am Main: Peter Lang GmbH.

KALIUŠČCENKO, V. D. (1988): Deutsche denominale Verben, Tübingen: Narr.

KAUFMANN, I. (1989): Direktive Präpositionen Raumkonzepte in Verstehensprozessen:

Interdisziplinäre Beiträge zu Sprache und Raum, Tübingen: Niemeyer.

KAUFMANN, I. (1995): Konzeptuelle Grundlagen semantischer Dekompositionsstrukturen. Die Kombinatorik lokaler Verben und prädikativer Elemente, Tübingen: Niemeyer.

KEMMER, S. \& VERHAGEN, A. (1994): "The grammar of causatives and the conceptual structure of events", Cognitive Linguistics, 5-2, pp. 115-156.

KRASSIN, G. (1984): Das Wortfeld der Fortwebegungsverben im modernen Französisch, Frankfurt am Main; Bern; New York.

KUTSCHER, S. (2009): Kausalität und Argumentrealisierung: Zur Konstruktionsvarianz bei Psychverben am Beispiel europäischer Sprachen. Max Niemeyer Verlag: Tübingen.

KÜHNHOLD, I., WELLMANN, H. (1973): Deutsche Wortbildung. Erster Hauptteil: Das Verb. Sprache der Gegenwart, Bd. XXIX., Pädagogischer Verlag Schwann.

LAKOFF, G. (1968): "Some verbs of change and causation", Mathematical linguistics and automatic translation, pp. 1-27.

LEISI, E. (1975): Der Wortinhalt: seine Struktur im Deutschen und Englischen, Heidelberg: Quelle\&Meyer.

LEVINSON, S. C., MAIENBORN, C. (1996): Situationen und Lokation: Die Bedeutung lokaler Adjunkte von Verbalprojektionen, Tübingen.
MAIENBORN, C. (1990): "Position und Bewegung: Zur Semantik lokaler Verben". IWBS-Report Nr. 138, IBM Stuttgart.

MAIENBORN, C. (1996): Situation und Lokation: Die Bedeutung lokaler Adjunkte von Verbalprojektionen. Tübingen: Stauffenburg.

NEDYALKOV, V. P. \& SILNITSKY, G. G. (1969): The Typology of Morphological and Lexical Causatives.Trends in Soviet Theoretical Linguistics, vol. 18.

NEDYALKOV, V. P. (1971): Kauzativnye konstrukcii $v$ nemeckom yazyke Analiticheskij kauzativ. L.: Nauka.

NEDYALKOV, V. P. (1988): Typology of resultative constructions. Typological studies in language, vol. 12, Amsterdam: John Benjamins.

NEWMANN, J. (2002): "The linguistics of sitting, standing and lying". Typological Studies in Language, vol. 51. Amsterdam and Philadelphia: John Benjamins Publishing Company.

PERSSON, I. (1975): Das System der kausativen Funktionsverbgefüge. Eine semantisch-syntaktische Analyse einiger verwandter Konstruktionen, Lund: LiberLärmedel.

SERRA, B. C. (1996): "Liegen and stehen in German: A study in horizontality and verticality", Cognitive Linguistics Research 6: Cognitive Linguistics in the Redwoods; the Expansion of a New Paradigm in Linguistics, Berlin and New York: Mouton de Gruyter, pp. 27-53.

SCHRÖDER, J. (1983): "Fortbewegungsverben als Beschreibungsprobleme (Simplizia Adverbialzusätze be-Präfixe)", $D a F$ 23, S. pp. 213-219.

SHIBATANI, M. (1976): "The grammar of causative construction", Syntax and Semantics, v. 6, pp. 1-40.

SILNITSKY, G. G. (1974): Semanticheskie $i$ valentnostnye klassy anglijskih kauzativnyh glagolov. L.: Nauka.

STEINITZ, R. (1998): Lokatives Verb, Präpositionalphrasen und Prädikativkonstruktionen, Leipzig: Humboldt-Universität. 
STIEBELS, B. (1996): Lexikalische Argumente und Adjunkte. Zum semantischen Beitrag von verbalen Präfixen und Partikeln, Berlin: Akademie Verlag.

STORCH, G. (1978): Semantische Untersuchungen zu den inchoativen Verben im Deutschen, Schriften zur Linguistik, Bd. 9, Braunschweig: Vieweg.

STUPAK, I. (2010): "Zasoby` vy razhennya lokaty vny $x$ aktantiv poxidny $x$ kauzaty vny`x diyesliv u nimecz kij ta ukrayins kij movax", Naukovi zapy`sky. Vy pusk, 89(3), pp. 8590.

STUPAK, I. (2016): Word Formation of Derived Causative Verbs in German and Ukrainian. GRIN Verlag.

STUPAK, I. (2018): "Possessive abgeleitete kausative Verben im Deutschen und Ukrainischen", Analele Universitătii din Craiova, Seria ŞtiințeFilologige, Lingvistică, Anul XL, Nr. 1-2, S. pp. 432-447.

TALMY, L. (1985): "Lexicalization patterns: Semantic structure in lexical forms", Language typology and syntactic description, vol 3, pp. 50101.
VIHOVANEC', I. R. (1988): Chastini moviv semantiko-gramatichnomu aspekti, K.: Naukova dumka.

VOZNIJ, T. (1981): Slovotvir diesliv $v$ ukraïns'kij movi u porivnyanni $z$ rosijs'koyu ta bilorus'koyu, L'viv: Vishcha shkola.

WEISGERBER, L. (1962): Grundzüge der inhaltsbezogenen Grammatik, Düsseldorf: Schwann.

WUNDERLICH, D. (1985): "Über die Argumente des Verbs", Linguistische Berichte 97, S. pp. 183-227.

WUNDERLICH, D. \& HERWEG, M. (1991): 'Lokale und Direktionale, Semantik". Ein internationales Handbuch der Forschung, S. pp. 758-785.

WUNDERLICH, D. (1997): "Cause and the structure of verbs", Linguistic Inquiry, 28, pp.28-68.

ZIFONUN, G. (1973): Zur Theorie der Wortbildung am Beispiel deutscher Präfixverben, München: Max Hueber Verlag.

ZIMMER, K. (1976): "Some Remarks on Turkish Causatives". Syntax and Semantics, vol. 6, pp. 399-412. 